\title{
HUBUNGAN PENGETAHUAN KELUARGA DENGAN KEKAMBUHAN PASIEN SKIZOFRENIA DI RUMAH SAKIT JIWA PROVINSI LAMPUNG
}

\author{
Teguh Pribadi ${ }^{1}$, Yansuri $^{2}$, Indra Maulana ${ }^{3}$
}

${ }^{1}$ Program Studi Ilmu Keperawatan Universitas Malahayati Bandar Lampung Email : teguh@malahayati.ac.id

${ }^{2}$ Rumah Sakit Jiwa Provinsi Lampung

Email : yansuri33@gmail.com

${ }^{3}$ Fakultas Ilmu Keperawatan, Universitas Padjadjaran Bandung.

Email : indra.maulana@unpad.ac.id

\section{ABSTRACT : THE RELATIVES' KNOWLEDGE ABOUT SCHIZOPHRENIA AND RECURRENCES AMONG PATIENTS WITH SCHIZOPHRENIA AT LAMPUNG MENTAL HOSPITAL}

Background: Based on the prevalence of people with schizophrenia in Indonesia is $0.3-1$ percent of Indonesia's population or about 2 million people suffering from schizophrenia. Based on data obtained from Lampung Province Mental Hospital in 2015 there were 27,490 patients, and 19,907 patients had been recurrences. The results of pre-survey conducted on 10 patients's family, obtain of 7 (70\%) patients' families do not know how to prevent recurrence, the patients with schizophrenia

Purpose: Knowing that the relationship of relatives' knowledge about schizophrenia and recurrences among patients with schizophrenia at Lampung Mental Hospital-Province of Lampung 2018.

Methods: The type of this research was quantitative and Analytic Survey design with cross sectional approach, population and sample was all families who have family members with schizophrenia. The sample technique in this research was an accidental sampling, and the sample recruited as 236 respondents. The research conducted at Mental Hospital of Lampung Province with questionnaire and statistic test using Chi square test.

Results: Knowledge known relatives of schizophrenic patients in poor category of $121(51.3 \%)$ respondents, and patients experienced of relapse 120 (50.8\%) respondents, with a p-value $=0.000$.

Conclusion: There was the relationship between of relatives' knowledge and relapse among patients with schizophrenia at Lampung Mental Hospital-Province of Lampung 2018. It is suggestion to management hospital to be improve in health education especially to family who is taking care to the patients and consideration to prevent patients become relapse.

Keywords: Knowledge, Family, Schizophrenia, Relapse

\section{INTISARI: HUBUNGAN PENGETAHUAN KELUARGA DENGAN KEKAMBUHAN PASIEN SKIZOFRENIA DI RUMAH SAKIT JIWA PROVINSI LAMPUNG}

Pendahuluan : Berdasarkan Prevalensi penderita skizofrenia di Indonesia adalah 0,3-1 persen penduduk Indonesia atau sekitar 2 juta jiwa menderita skizofrenia. Berdasarkan data yang diperoleh dari Rumah Sakit Jiwa Provinsi Lampung tahun 2015 tercatat 27.490 kunjungan pasien jiwa, dan terdapat 19.907 pasien mengalami kekambuhan. Hasil pra survey yang dilakukan terhadap 10 keluarga 
pasien didapat 7 (70\%) orang keluarga pasien yang kurang memahami, bagaimana mencagah kekambuhan pada pasien tersebut.

Tujuan: Diketahui Hubungan Pengetahuan Keluarga Dengan Kekambuhan Pasien Skizofrenia Di Rumah Sakit Jiwa Provinsi Lampung Tahun 2018

Metode : Jenis penelitian ini adalah kuantitatif, dengan Rancangan penelitian menggunakan desain Survei Analitik dengan pendekatan cross sectional, jumlah populasi dan sampel adalah seluruh keluarga yang memiliki anggota keluarga dengan skizofrenia di RS Jiwa Daerah Provinsi Lampung, teknik sampel dalam penelitian ini adalah accidental sampling, dengan jumlah sampel sebanyak 236 responden, dengan instrument penelitian kuisioner dan uji statistic menggunakan uji Chi square.

Hasil : Diketahui Pengetahuan keluarga pasien skizofrenia adalah kurang baik yaitu sebesar $121(51.3 \%)$ responden. Sebagian besar pasien skizofrenia mengalami kekambuhan yaitu sebesar 120 (50.8\%) responden, dengan nilai $p$ value $=0.000$.

Simpulan : Ada hubungan pengetahuan keluarga dengan kekambuhan pasien skizofrenia di Rumah Sakit Jiwa Provinsi Lampung Tahun 2018. Disarankan kepada manajemen rumah sakit untuk meningkatkan pendidikan kesehatan terutama untuk keluarga yang merawat pasien dan pertimbangan untuk mencegah pasien menjadi kambuh.

Kata Kunci: Pengetahuan, Keluarga, Skizofrenia, Kekambuhan

\section{PENDAHULUAN}

Jiwa adalah unsur manusia

yang bersifat nonmateri, tetapi fungsi dan manifestasinya sangat terkait pada materi. Manifestasi jiwa antara lain tampak pada kesadaran, afek, emosi, psikomotor, proses berpikir, persepsi, dan sifat kepribadian. (Zainal, 2015). Gangguan jiwa merupakan manifestasi dari bentuk penyimpangan perilaku akibat adanya distorsi emosi sehingga ditemukan ketidakwajaran dalam bertingkah laku. Hal ini terjadi karena menurunnya semua fungsi kejiwaan. (Nasir, \& Muhith, 2011)

$$
\text { Seseorang mengalami }
$$
gangguan jiwa apabila ditemukan adanya gangguan pada fungsi mental, yang meliputi: emosi, pikiran, perilaku perasaan, motivasi, kemauan, keinginan, daya tilik diri, dan persepsi sehingga mengganggu dalam proses hidup di masyarakat (Puspitasari, 2016). Hal ini dipicu oleh adanya persepsi sehingga seseorang untuk memenuhi kebutuhan dasar manusia dalam

$\begin{array}{lrr}\text { mempertahankan hidup } & \text { sehingga } \\ \text { seseorang dihadapkan } & \text { untuk } \\ \text { berpikir, berkeinginan } & \text { untuk } \\ \text { mencapai cita-cita } & \text { yang } \\ \text { mengharuskan } & \text { seseorang } \\ \text { berhubungan dengan orang lain } \\ \text { (Nasir, 2011) }\end{array}$

Secara umum, klasifikasi gangguan jiwa menurut hasil Riset Kesehatan Dasar tahun 2013 dibagi menjadi dua bagian, yaitu 1) gangguan jiwa berat/ kelompok psikosa dan 2) gangguan jiwa ringan meliputi semua gangguan mental emosianal yang berupa kecemasan, panik, gangguan alam perasaan, dan sebagainya. Untuk skizofrenia masuk dalam kelompok gangguan jiwa berat (Sulistyorini, Widodo \& Zulaicha (2013).

Fenomena gangguan jiwa pada saat ini mengalami peningkatan yang sangat signifikan, dan setiap tahun di berbagai belahan dunia jumlah penderita gangguan jiwa bertambah. Berdasarkan data dari World Health Organisasi (WHO) dalam Yosep (2013), ada sekitar 450 juta orang di dunia yang mengalami 
gangguan jiwa. WHO menyatakan setidaknya ada satu dari empat orang didunia mengalami masalah mental, dan masalah gangguan kesehatan jiwa yang ada di seluruh dunia sudah menjadi masalah yang sangat serius (Yosep, 2013).

Dalam masyarakat umum skizofrenia terdapat $0,2-0,8 \%$ dan retardasai mental $1-3 \%$. WHO melaporkan bahwa 5-15\% dari anakanak antara 3-15 tahun mengalami gangguan jiwa yang persistent dan mengganggu hubungan sosial. Bila kira-kira 40\% penduduk negara kita adalah anak-anak di bawah 15 tahun (dinegara yang sudah berkembang kira-kira 25\%), dapat digambarkan besarnya masalah (ambil saja 5\% dari 40\% dari katakan saja 120 juta penduduk, maka dinegara kita terdapat kira-kira 2.400.000 orang anak yang mengalami gangguan jiwa) (Maramis, 2009).

Skizofrenia merupakan gangguan mental yang beratyang mempengaruhi sekitar 7 per seribudari populasi orang dewasa, terutama dikelompok usia 15-35 tahun. Meskipuninsiden rendah (310.000), prevalensi yangtinggi terjadi karena kronisitas (Pratama \& Syahrial, 2015).

Penderita gangguan jiwa berat dengan usia di atas 15 tahun di Indonesia mencapai $0,46 \%$. Hal ini berarti terdapat lebih dari 1 juta jiwa di 2 Indonesia yang menderita gangguan jiwa berat. Berdasarkan data tersebut diketahui bahwa 11,6\% penduduk Indonesia mengalami masalah gangguan mental emosional (Kementrian Kesehatan Republik Indonesia, 2007). Sedangkan pada tahun 2013 jumlah penderita gangguan jiwa mencapai 1,7 juta (Kementrian Kesehatan Republik Indonesia, 2013).

Prevalensi

penderita

skizofrenia di Indonesia adalah 0,3-1 persen. Apabila penduduk Indonesia sekitar 200 juta jiwa, maka diperkirakan sekitar 2 juta jiwa menderita skizofrenia. Skizofrenia merupakan gangguan mental yang sangat luas di Indonesia, dimana sekitar 99\% pasien di RS jiwa di Indonesia adalah penderita skizofrenia (Arif, 2006).

Berdasarkan data yang diperoleh dari Rumah Sakit Jiwa Provinsi Lampung tahun 2015 tercatat 27.490 kunjungan pasien jiwa yang rawat jalan, 2.606 merupakan pasien baru dan 24.884 merupakan pasien lama, dimana 17.924 laki dan 9.566 perempuan, dari data 24.884 pasien lama terdapat 19.907pasien mengalami kekambuhan. Sedangkan Data terakhir pada bulan JuliDesember2017 didapatkan 375 kunjungan pasien jiwa yang rawat jalan (Rumah Sakit Jiwa Provinsi Lampung, 2015).

Salah satu faktor penyebab kekambuhan pasien skizofrenia adalah perilaku keluarga yang tidak tahu cara menangani pasien skizofrenia di rumah. Perawatan di rumah sakit tidak akan bermakna apabila tidak dilanjutkan dengan perawatan di rumah. Untuk dapat melakukan perawatan yang baik dan benar, keluarga perlu mempunyai bekal pengetahuan tentang penyakit yang dialami penderita, salah satunya adalah gangguan fungsi kognitif. Oleh sebab itu, orang terdekat penderita seperti keluarga, pengasuh, dan masyarakat berperan sangat penting dalam penanganan penderita skizofrenia. Salah satu faktor yang memengaruhi kekambuhan pada penderita skizofrenia adalah pengetahuan keluarga. Keluarga diharapkan dapat lebih mengerti, mengetahui dan memahami dan pada akhirnya dapat berperan secara aktif sebagai pendukung utama penderita. Selain itu, meningkatkan kemampuan penyesuaian diri serta tidak rentan lagi terhadap pengaruh stressor 
psikososial. Sebagian besar keluarga penderita skizofrenia masih kurang memiliki informasi yang memadai tentang skizofrenia, perjalanan penyakit, dan tata laksana untuk mengupayakan rehabilitasi pasien.

Berdasarkan data di rumah sakit Jiwa Provinsi Lampung pada tahun 2017dari 348 orang diketahui tidak mengalami kekambuhan 100 orang $(28,7 \%)$ dan mengalami kekambuhan 248 orang $(71,3 \%)$.

Hasil prasurvey yang dilakukan terhadap 10 keluarga yang sedang mengantar anggota keluarganya untuk membesuk pasien yang sedang menjalani perawatan, diketahui bahwa sebanyak 7 orang (70\%) pasien pernah kambuh, sedangkan 3 orang (30\%) pasien tidak mengalami kekambuhan. Hasil wawancara bebas yang dilakukan terhadap 10 keluarga pasien diketahui bahwa 8 keluarga memiliki pengetahuan kurang tentang cara perawatan pasien dengan gangguan jiwa.

Berdasarkan latar belakang diatas maka peneliti tertarik melakukan penelitian dengan judul "hubungan pengetahuan keluarga dengan kekambuhan pasien skizofrenia di Rumah Sakit Jiwa Provinsi Lampung Tahun 2018"

\section{METODE PENELITIAN}

Jenis penelitian yang digunakan dalam penelitian ini adalah kuantitatif yaitu data yang diperoleh dari hasil pengukuran, maupun dari nilai suatu data yang diperoleh dengan jalan mengubah data kualitatif ke dalam data kuantitatif, misalnya skors dari hasil tes, atau hasil dari penghitungan. (Notoatmodjo, 2012). Tempat penelitian ini di instalasi rawat jalan Rumah Sakit Jiwa Daerah Provinsi Lampung.

Penelitian dilakukan dengan metode survey analitik menggunakan pendekatan studi cross sectional. Dalam Penelitian cross sectional (Potong lintang), variabel sebab dan kasus yang terjadi pada objek penelitian diukur atau dikumpulkan secara simultan (dalam waktu yang bersamaan). Pengumpulan data dalam penelitian ini dilakukan secara bersama-sama atau sekaligus (Riyanto, 2011).

Populasi dalam penelitian ini adalah seluruh keluarga pasien yang melakukan kontrol ulang di Instalasi rawat jalan Rumah Sakit Jiwa Provinsi Lampung sebanyak 236 responden (setiap 1 orang dari keluarga pasien) dan 236 pasien untuk dilihat medical record (MR) untuk melihat riwayat kekambuhannya.

HASIL

Analisa Univariat

Tabel 1. Distribusi Frekuensi Pengetahuan Keluarga Pasien Skizofrenia $(\mathrm{N}=236)$.

\begin{tabular}{ccc}
\hline Pengetahuan & Jumlah & Persentase (\%) \\
\hline Baik & 115 & 48.7 \\
Kurang Baik & 121 & 51.3 \\
Total & 236 & 100 \\
\hline
\end{tabular}

Berdasarkan table 1 diatas, dapat dilihat jika sebagian besar pengetahuan keluarga pasien skizofrenia adalah kurang baik yaitu sebesar 121 responden (51.3\%) dan pengetahuan baik 115 responden $(48.7 \%)$. 
Tabel 2. Distribusi Frekuensi Kekambuhan Pasien Skizofrenia $(\mathbf{N}=236)$.

\begin{tabular}{ccc}
\hline Kekambuhan & Jumlah & Persentase (\%) \\
\hline Tidak Kambuh & 116 & 49.2 \\
Kambuh & 120 & 50.8 \\
Total & 236 & 100 \\
\hline
\end{tabular}

Berdasarkan tabel 2 diatas, dapat dilihat jika sebagian besar pasien skizofrenia mengalami kekambuhan yaitu sebesar 120 responden $(50.8 \%)$ dan yang tidak kambuh 116 responden $(49.2 \%)$.

Analisa Bivariat

Tabel 3. Hubungan Pengetahuan Keluarga Dengan Kekambuhan Pasien Skizofrenia

\begin{tabular}{|c|c|c|c|c|c|c|c|c|}
\hline \multirow[t]{3}{*}{ Pengetahuan } & \multicolumn{4}{|c|}{ Kekambuhan } & \multirow{2}{*}{\multicolumn{2}{|c|}{ Total }} & \multirow{3}{*}{$\begin{array}{l}\text { P- } \\
\text { Value }\end{array}$} & \multirow{3}{*}{$\begin{array}{l}\text { OR } \\
\text { Cl 95\% }\end{array}$} \\
\hline & \multicolumn{2}{|c|}{ Tidak } & \multicolumn{2}{|c|}{ Kambuh } & & & & \\
\hline & $\mathrm{n}$ & $\%$ & $\mathrm{n}$ & $\%$ & $\mathbf{N}$ & $\%$ & & \\
\hline Baik & 90 & 38.1 & 25 & 10.6 & 115 & 48.7 & & 13.154 \\
\hline Kurang Baik & 26 & 11.0 & 95 & 40.3 & 121 & 51.3 & 0.000 & (7.075- \\
\hline Total & 116 & 49.2 & 120 & 50.8 & 236 & 100 & & 24.455) \\
\hline
\end{tabular}

Dari tabel 3 diatas dapat dilihat hasil pengetahuan keluarga tentang kekambuhan pada pasien skizofrenia dengan kategori baik sebanyak 115 responden (48.7\%) dan pasien tidak kambuh sebanyak 90 responden (38.1\%) sedangkan pasien yang mengalami kekambuhan sebanyak 25 responden (10.6\%) sedaangkan keluarga dengan pengetahuan buruk sebanyak 121 responden (51.3\%) dengan pasien tidak kambuh sebanyak 26 responden $(11.0 \%)$ dan pasien yang mengalami kekambuhan sebanyak 95 responden (40.3\%).

Dengan hasil uji statistic chisquare didapat nilai $p$-value $=0.000$ $(<0.05)$ yang artinya ada hubungan pengetahuan keluarga dengan kekambuhan pasien skizofrenia di Rumah Sakit Jiwa Provinsi Lampung Tahun 2018. Dengan nilai $O R=$ 13.154 yang artinya keluarga dengan pengetahuan kurang baik akan beresiko 13 kali memiliki kekambuhan pada keluarga dengan penyakit skizoferenia.

\section{PEMBAHASAN}

Analisa Univariat

Distribusi Frekuensi Pengetahuan Keluarga Pasien dengan Skizofrenia

Berdasarkan tabel 1 diatas, dapat dilihat jika sebagian besar pengetahuan keluarga pasien skizofrenia adalah kurang baik yaitu sebesar 121 responden $(51.3 \%)$ dan pengetahuan baik 115 responden (48.7\%).

Pengetahuan adalah hasil tahu, dan ini terjadi setelah orang melakukan pengindraan terhadap suatu objek tertentu. Pengindraan terjadi melalui pancaindra manusia, yakni : indra penglihatan, pendengaran, penciuman, rasa, dan raba. Sebagian besar pengetahuan manusia diperoleh melalui mata dan telinga (Notoatmodjo, 2008)

Menurut peneliti, pengetahuan seseorang dapat dipengaruhi oleh pendidikan yang ditempuh selama 
ini, semakin tinggi pendidikan, sama artinya dengan semakin banyak informasi dansumber informasi yang didapat, selainitu, sharing sesama rekan atau orang dilingkungan tempat tinggal atau sekitar pekerjaan dan orang yang memiliki keluarga dengan riwayat gangguan jiwa, akan meningkatkan pengetahuan responden tentang merawat pasien dengan skizofrenia

\section{Distribusi Frekuensi Kekambuhan Pasien dengan Skizofrenia}

Berdasarkan tabel 2 diatas, dapat dilihat jika sebagian besar pasien skizofrenia mengalami kekambuhan yaitu sebesar 120 responden (50.8\%) dan yang tidak kambuh 116 responden (49.2\%).

Sejalan dengan teori yang dikemukanakan oleh Tri (2012) Kambuh merupakan seseorang yang jatuh sakit lagi sesudah sembuh atau serangan (bangkitnya) kembali penyakit yang telah sembuh. Kambuh merupakan keadaan klien dimana muncul gejala yang sama seperti sebelumnya dan mengakibatkan klien harus dirawat kembali. Kekambuhan biasanya terjadi karena adanya kejadiankejadian buruk sebelum mereka kambuh (Wiramihardja, 2007).

Beberapa gejala kambuh yang diidentifikasi oleh klien dan keluarganya, biasanya klien merasa nervous, tidak nafsu makan, sukar konsentrasi, sulit tidur, depresi, tidak ada minat, dan menarik diri Yaqin, Widodo, \& Susilaningsih (2015), . Pada gangguan jiwa psikotik akan timbul gejala positif yang aktif seperti waham, halusinasi, gangguan pikir, ekopasia, asosiasi longgar, flight of ideas (Videbeck, 2008)

Menurut peneliti kambuh artinya pasien kembali mengalami sakit, atau kegagalan merawat diri sendiri baik dibantu keluarga atau tim medis lainnya. Kekambuhan pasien skizofrenia dapat disebabkan oleh beberapa sebab diantaranya adalah pengetahuan keluarga dalam merawat pasien tersebut, keluarga harus dituntut memahami karakter pasien, pengobatan, kunjungan rutin, dan penanganan jika pasien kembali relaps.

Analisa Bivariat

\section{Hubungan Pengetahuan Keluarga Dengan Kekambuhan Pasien Skizofrenia \\ Dengan hasil uji statistic chi-} square didapat nilai $p$-value $=0.000$ $(<0.05)$ yang artinya ada hubungan pengetahuan keluarga dengan kekambuhan pasien skizofrenia di Rumah Sakit Jiwa Provinsi Lampung Tahun 2018. Dengan nilai $O R=$ 13.154 yang artinya keluarga dengan pengetahuan kurang baik akan beresiko 13 kali memiliki kekambuhan pada keluarga dengan penyakit skizoferenia.

Pada penelitian ini masih terdapat 115 responden dengan pengetahuan baik dan pasien tidak kambuh sebanyak 90 responden hal ini disebabkan karena keluarga dapat merawat pasien dengan baik, sedangkan pasien yang mengalami kekambuhan sebanyak 25 responden, hal ini disebabkan karena faktor dari pasien itu sendiri, dna kurangnya pengobatan yang dijalanin, sedaangkan keluarga dengan pengetahuan buruk sebanyak 121 responden dengan pasien tidak kambuh sebanyak 26 responden hal ini bisa disebabkan karena pengetahuan saat dilakukan penelitian adalah pemngetahuan dari sanak saudara yang ikut serta dalam kunjungan, dan bukan orang yang merawat pasien tersebut dan pasien yang mengalami kekambuhan sebanyak 95 pasien skizofrenia mengalami kekambuhan, dari penelitian ini dapat diketahui, jika sebagian besar keluarga kurang memahami cara perawatan dan 
pengobatan bagi pasien skizofrenia, yang berdampak pada kekambuhan pasien

Sejalan dengan teori yang dikemukakan oleh Ibrahim (2011) pentingnya peran serta keluarga dalam klien gangguan jiwa dapat dipandang dari berbagai segi. Pertama, keluarga merupakan tempat diman individu memulai hubungan interpersonal dengan lingkungannya. Keluarga merupakan "institusi" pendidikan utama bagi individu untuk belajar dan mengembangkan nilai, keyakinan, sikap dan perilaku. Individu menguji coba perilakunya di dalam keluarga, dan umpan balik keluarga memengaruhi individu dalam mengadopsi perilaku tertentu. Semua ini merupakan persiapan individu untuk berperan di masyarakat. Jika keluarga di pandang suatu sistem, maka gangguan yang terjadi pada salah satu anggota merupakan salah satu anggota keluarga, dapat mempengaruhi seluruh sistem, sebaliknya disfungsi keluarga merupakan salah satu penyebab gangguan pada anggota. Pelayanan kesehatan jiwa yang ada merupakan fasilitas yang membantu klien dan keluarga dalam mengembangkan kemampuan mencegah terjadinya maslaah, menanggulangi berbagai masalah, dan mempertahankan keadaan adaftif. Salah satu faktor penyebab kambuh gangguan jiwa adalah keluarga yang tidak tahu cara menangani perilaku klien di rumah.

Menurut pendapat peneliti salah satu faktor penyebab kekambuhan pasien skizofrenia adalah perilaku keluarga yang tidak tahu cara menangani pasien skizofrenia di rumah. Perawatan di rumah sakit tidak akan bermakna apabila tidak dilanjutkan dengan perawatan di rumah. Untuk dapat melakukan perawatan yang baik dan benar, keluarga perlu mempunyai bekal pengetahuan tentang penyakit yang dialami penderita, salah satunya adalah gangguan fungsi kognitif. Oleh sebab itu, orang terdekat penderita seperti keluarga, pengasuh, dan masyarakat berperan sangat penting dalam penanganan penderita skizofrenia.

Keluarga diharapkan dapat lebih mengerti, mengetahui dan memahami dan pada akhirnya dapat berperan secara aktif sebagai pendukung utama penderita. Selain itu, meningkatkan kemampuan penyesuaian diri serta tidak rentan lagi terhadap pengaruh stressor psikososial. Sebagian besar keluarga penderita skizofrenia masih kurang memiliki informasi yang memadai tentang skizofrenia, perjalanan penyakit, dan tata laksana untuk mengupayakan rehabilitasi pasien.

\section{SIMPULAN}

Pengetahuan keluarga pasien skizofrenia adalah kurang baik yaitu sebesar 121 responden (51.3\%), sebagian besar pasien skizofrenia mengalami kekambuhan yaitu sebesar 120 responden (50.8\%). Hasil uji statistic chi-square didapat nilai $p$-value $=0.000(<0.05)$ yang artinya ada hubungan pengetahuan keluarga dengan kekambuhan pasien skizofrenia di Rumah Sakit Jiwa Provinsi Lampung Tahun 2018.

\section{SARAN}

Hasil penelitian ini diharapkan dapat menambah wawasan dan ilmu pengetahuan kesehatan kerja terutama tentang hubungan pengetahuan keluarga dengan kekambuhan pasien skizofrenia. Selain itu hasil penelitian ini juga dapat dijadikan bahan bacaan bagi mahasiswa yang akan melakukan penelitian atau tugas yang berkaitan dengan skizofrenia. Berdasarkan hasil penelitian ini diharapkan dapat dijadikan sebagai sumber informasi 
dan bahan pertimbangan di dalam mengatasi permasalahan yang timbul terutama dalam pencegahan kekambuhan pasien jiwa. Bagi keluarga diharapkan untuk selalu meningkatkanpengetahuan tentang penanganan terhadap keluarga yang memilik anggota keluarga dengan gangguan kejiwaan, karena orang gangguan jiwa juga memiliki hak untuk diperlakukan sama dengan manusia normal seutuhnya.

\section{DAFTAR PUSTAKA}

Arif, I. S. (2006). Skizofrenia memahami dinamika keluarga pasien. Bandung: Refika Aditama.

Filsafat, Lodika dan Filsafat Ilmu 'Epistemologi', Metafisika dan Filsafat Manusia, dan Aksiologi). Bandung Aditama.

Ibrahim, A. S. (2011). Ansietas (Takut Mati) Cemas, Was-was dan Khawatir.

Kementrian Kesehatan Republik Indonesia. (2007). Laporan nasional 2007. Badan Penelitian dan Pengembangan Kesehatan Departemen Kesehatan, Republik Indonesia. Jakarta: Depkes.

Kementrian Kesehatan Republik Indonesia. (2013). Riset kesehatan dasar (Riskesdas) 2013. Jakarta: Badan Penelitian dan Pengembangan Kesehatan.

Nasir, A., \& Muhith, A. (2011). Dasardasar keperawatan jiwa: pengantar dan teori. Jakarta: Salemba Medika.

Notoatmodjo, S. (2012). Promosi kesehatan dan perilaku kesehatan. Jakarta: Rineka Cipta, 45-62.

Pratama, Y., \& Syahrial, S. (2015). Hubungan Keluarga Pasien Terhadap Kekambuhan Skizofrenia Di Badan Layanan Umum Daerah (Blud) Rumah Sakit Jiwa Aceh. Jurnal Kedokteran Syiah Kuala, 15(2), 77-86.

Puspitasari, D. P. (2016). Hubungan Fungsi Perawatan Kesehatan Keluarga Dengan Kekambuhan Pada Pasien Gangguan Jiwa Di Rumah Sakit Jiwa H. Mustajab Purbalingga (Doctoral Dissertation, Universitas Muhammadiyah Purwokerto).

Riyanto, A. (2011). Aplikasi metodologi penelitian kesehatan.

Sulistyorini, N., Widodo, A., Ke, M. \& Zulaicha, E.,. (2013). Hubungan pengetahuan tentang gangguan jiwa terhadap sikap masyarakat kepada penderita gangguan jiwa di Wilayah Kerja Puskesmas Colomadu 1 (Doctoral dissertation, Universitas Muhammadiyah Surakarta).

Videbeck, S. L. (2008). Buku ajar keperawatan jiwa. Jakarta: EGC, 78-98.

Vira (2012). Promosi kesehatan dan perilaku kesehatan. Jakarta: Rineka Cipta, 45-62.

Willy, M., \& Maramis Albert, A. (2009). Catatan Ilmu Kedokteran Jiwa Edisi 2.

Wiramihardja, A. S. (2007). Pengantar Filsafat, Sistematika Filsafat, Sejarah. 
Yaqin, T. F., Widodo, A., \& Susilaningsih, E.,Z. (2015). Hubungan Pengetahuan Keluarga Tentang Tanda Dan Gejala Skizofreniaparanoid Dengan Upaya Mencegah Kekambuhan Pasien Di RSJD Surakarta (Doctoral dissertation, Universitas Muhammadiyah Surakarta).
Yosep, I. (2013). Keperawatan jiwa. Bandung: Refika Aditama.

Zainal, Y.( 2015). Manajemen Komunikasi: Filosofi, Konsep, dan Aplikasi. Bandung: Pustaka Setia.

Notoatmodjo, S. (2008). Metodologi Penelitian Cetakan 4. Jakarta: Rineka Cipta. 